\title{
Economic Expectations of the Belt and Road Initiative for the South Caucasus, with Emphasis on Georgia
}

\author{
Iza Gigauri \\ Associate Professor of Caucasus University \\ Caucasus School of Business, Republic of Georgia \\ E-mail: izagigauri@gmail.com
}

\begin{abstract}
Nino Damenia
Associated Professor, Deputy Dean of School of Business, Computing and Social Sciences St. Andrew the First-Called Georgian University of the Patriarchate of Georgia Republic of Georgia
\end{abstract}

Tel: 995-599-712-284Ｅ-mail: n.damenia@sangu.edu.ge

Received: January 25, 2019 Accepted: February 15, 2019 Published: February 28, 2019

doi:10.5296/ber.v9i1.14438

URL: https://doi.org/10.5296/ber.v9i1.14438

\begin{abstract}
Georgia, a post-soviet country, located in the South Caucasus at a crossroads of Europe and Asia, presents Europe's natural gateway towards Asia. The Belt and Road Initiative, also known as the One Belt One Road, is 21st century Silk Road encompassing transportation and communication systems connecting China to Europe. Since the Initiative is at its beginning stage, it is essential to study its economic influence on the South Caucasus region it traverses, and particularly, upon Georgia. In this respect, to facilitate sustainable growth in the region, advanced technology, industrial and infrastructural modernization is crucial. Under the Initiative, Baku-Tbilisi-Kars railway is completed, which can significantly shorten the time of shipment from China to Europe, and Georgia's Anaklia Deep Sea Port on the Black Sea with a huge capacity of cargo transportation is under construction. The infrastructure investments under the Initiative can encourage economic development and hence, reduce poverty.
\end{abstract}

Keywords: Silk Road, One Belt One Road, Economic corridors, China, Economic development, Trade 


\section{Introduction}

International trade is at the center of global economy as a major driver for economic development. Both countries and businesses focus on emerging possibilities coming from the ancient trade routes, which have been replaced by modern transportation and communication systems making possible to exchange goods, culture, technology, and knowledge.

This exploratory and analytical research of secondary data aims at providing insight into the economic importance of the Silk Road for Georgia and for the South Caucasus. It aims at reviewing current literature and gathering statistical data with the purpose to reveal the key factors influencing the One Belt One Road (OBOR) initiative, as well as its main aspects having impact on Georgia and on the region.

This research studies opportunities for Georgia in view of emerging chances for regional economic development in the South Caucasus due to the economic corridors crisscrossing the region. The Chinese initiative of OBOR has the possibility of transforming the economies in the South Caucasus through investments and transportation links. Georgia is located on the Trans-Caspian corridor called the Middle Corridor. The presented research focuses on trade-related infrastructure, investments towards the realization of the middle corridor, as well as Chinese presence and involvement in the South Caucasus, and particularly investments in Georgia.

A future vision for the South Caucasus is underlined, because open borders allow unrestricted flows of goods, services, and people, which are precursors for economic growth, as well as new jobs and production networks can be created expectedly.

\section{Overview of the Belt and Road Initiative (BRI)}

Before the beginning of the ancient Silk Road in the 2nd century BC, the route from Europe to Asia stopped at the borders of China because of its geographical location. After the invention of silk - an extremely high value product in the ancient China around the year 2700 $\mathrm{BC}$, it was introduced to the Roman Empire during the 1st century BC, where it became popular as an exotic luxury. The textile was used as a diplomatic gift, traded extensively, and therefore, was one of the early impetuses in the development of trading routes from Europe to the Far East (UNESCO Webpage). For centuries, cities along the Silk Road traded goods between east and west, including jewels, spices, glassware, medicines, perfumes, and fine fabrics. Later, during the Romanov Dynasty and the Soviet era, a north-south trade axis overlay Eurasia, with Moscow as the main hub (Coulibaly et al., 2012). Consequently, a system of caravan roads emerged between East and West - the Great Silk Road, that was not only used for trade but also for diplomatic ties. Historically, empires tried to control the Silk Road, and there were periods when it was almost completely controlled by one state, but in general, it was impossible to control all its sectors due to its huge distance.

As Beckwith (2009) concludes, the Silk Road was not only a network of trade routes, or even a system of cultural exchange, but it was the entire local political-economic-cultural system of Central Eurasia, in which commerce, whether internal or external, was very highly valued and energetically pursued. In that sense, the "Silk Road" and "Central Eurasia" are essentially 
two terms for the same thing. In its more restricted economic sense, the Silk Road was the Central Eurasian economy (Beckwith, 2009).

The Caucasian Silk Road gained significance in the 6th-7th century, and has been used until 14th century before the great caravan routes seizing to traverse Caucasus.

As a result of the collapse of the Soviet economy, the connectivity between Eurasian cities has been weakened. Without subsidies for transporting goods and services from one city to another, the more remote cities are isolated from global markets and increasingly uncompetitive. Rail networks are hard to run efficiently, even with the lowest electricity prices in Europe. Road networks are expensive to maintain and upgrade. And air infrastructure is becoming more and more important for connecting a landmass that spans nine time zones (Coulibaly et al., 2012).

Overall, the significance of ancient Silk Road has been obviously great in terms of economic, political, social, and cultural development, not to mention its importance for the further development of the Eurasian continent.

Although the ancient Silk Road was a major trade link between the East and West, technological changes and dramatic declines in transportation costs have made it obsolete as trade shifted from the surface to the sea or air. Nevertheless, China with its Belt and Road Initiative (BRI) seeks to establish new connections between Europe and Asia based on railway connections and to revive the historic Silk Road (Li \& Schmerer, 2017). Obviously, the distance plays a key part, since most world trade occurs between countries that share a land border and half of world trade takes place between partners less than $3000 \mathrm{~km}$ apart. Besides, nearly all trade between distant partners has taken place using either ocean or air transportation modes. In this regard, the BRI initiative with its innovative nature looks to integrate distant trade nodes using railway networks (Li \& Schmerer, 2017).

In addition, as timely delivery is essential for modern production chains, cargo flights can guarantee on-time delivery. But freight weight, and size are still important determinants of transportation costs - whether air transportation costs or railways are the lower cost option. Accordingly, Intercontinental railways have recently made a significant progress in not only reducing the cost but also time of international shipments. For instance, in comparison with ocean shipping, intercontinental railways have reduced delivery times, and transportation costs by approximately $40 \%$ relative to air shipping (Li \& Schmerer, 2017). Moreover, surface connections permit direct transportation of goods between inland locations. Because of its growing e-commerce market, faster transportation of exports is becoming increasingly important for China. Since, e-commerce requires speed, there is potential to attract aviation to land routes on the Eurasian continent. In addition, time sensitive but heavy products, including car parts, processed food, and high technology products, may be better transported by rail, which is faster than sea but cheaper than air freight (Mount, 2014).

New global projects put forward by Beijing, known as the New Silk Road project or "One Belt, One Road" Initiative, include the Silk Road Economic Belt and the 21st Century Maritime Silk Road, both of which together create the Belt and Road Initiative, and covers the Asia-Pacific, Europe, Central Asia, South Asia, Southeast Asia, West Asia, and Africa 
(Charaia \& Papava, 2017). Under the OBOR initiative, China will be connected to Western Europe by both land-based and maritime transportation as well as communication networks.

Since its introduction in 2013, the map of the economic corridors reveals that the initiative has expanded into including many 'belts' and many 'roads'. Railway lines are growing fast and many cities are already connected with Central Asian and European trade partners. In addition, new seaports, airports, bridges and highways, oil and gas pipelines, electrical and fibre optic networks, as well as industrial parks are under construction along the route ( $\mathrm{Li} \&$ Schmerer, 2017; Inan \& Yayloyan, 2018). In fact, the OBOR Action Plan in 2015 had two main components: the Silk Road Economic Belt and the 21st Century Maritime Silk Road. The "belt" is the Eurasian land route connecting China to Europe; the "road" is a maritime trade route connecting Chinese or Chinese invested ports with the African coast and European Mediterranean ports (Inan \& Yayloyan, 2018).

Thus, the BRI encourage opportunities for economic development and cultural exchange between the regions spanned the Eurasian continent, including Central Asia, the Caucasus, the Black and Caspian Seas, the Mediterranean countries, and the European Union. Infrastructure investments integrating these countries may serve as a driver of productivity and economic growth helping reduce poverty (Li \& Schmerer, 2017).

\section{China's Powerful Impetus to the One Belt One Road Project}

China, as a major global economic power with its biggest economy in the world, introduces a comprehensive vision of economic development with its 'One Belt One Road' initiative for the region. It has made a grand entry not only into Central Asia but has also a growing presence in the South Caucasus. Besides, China is well established all across Central Asia most notably in the energy sector, as it is a primary importer of energy conditioned by its growing energy demand linked to its economic growth (Inan \& Yayloyan, 2018). Together with the physical infrastructure, policy coordination, financial integration, collaboration in trade, social and cultural cooperation are also required for the effectiveness of the new Silk Road Project. China has made major investments in infrastructure along OBOR routes. In 2014, China established the USD 40 billion Silk Road Fund and has promised to invest substantial resources in its OBOR initiative (Inan \& Yayloyan, 2018). New Economic Corridors are of great importance for China to connect faster and cheaper to the European market.

The European Union remains China's most important trade partner in Eurasia (Inan \& Yayloyan, 2018). Moreover, the geographical landmass between the EU and China - a supercontinent Eurasia covers $65 \%$ of the world's population, 30 to $40 \%$ of global GDP (Herrero \& Xu, 2016; Shepard, 2017), as well as 75\% of energy resources (Shepard, 2017). For this reason, Chinese trade interests may not simply be confined to accessing European markets but also take an opportunity to enter new markets along the way in a more direct way (Inan \& Yayloyan, 2018).

Currently, China's key trade partners remain Unites States, Korea, and Japan (Figure 1), whereas China is the second largest trade partner for the European Union outside the 
European Union (EU28) (Figure 2).

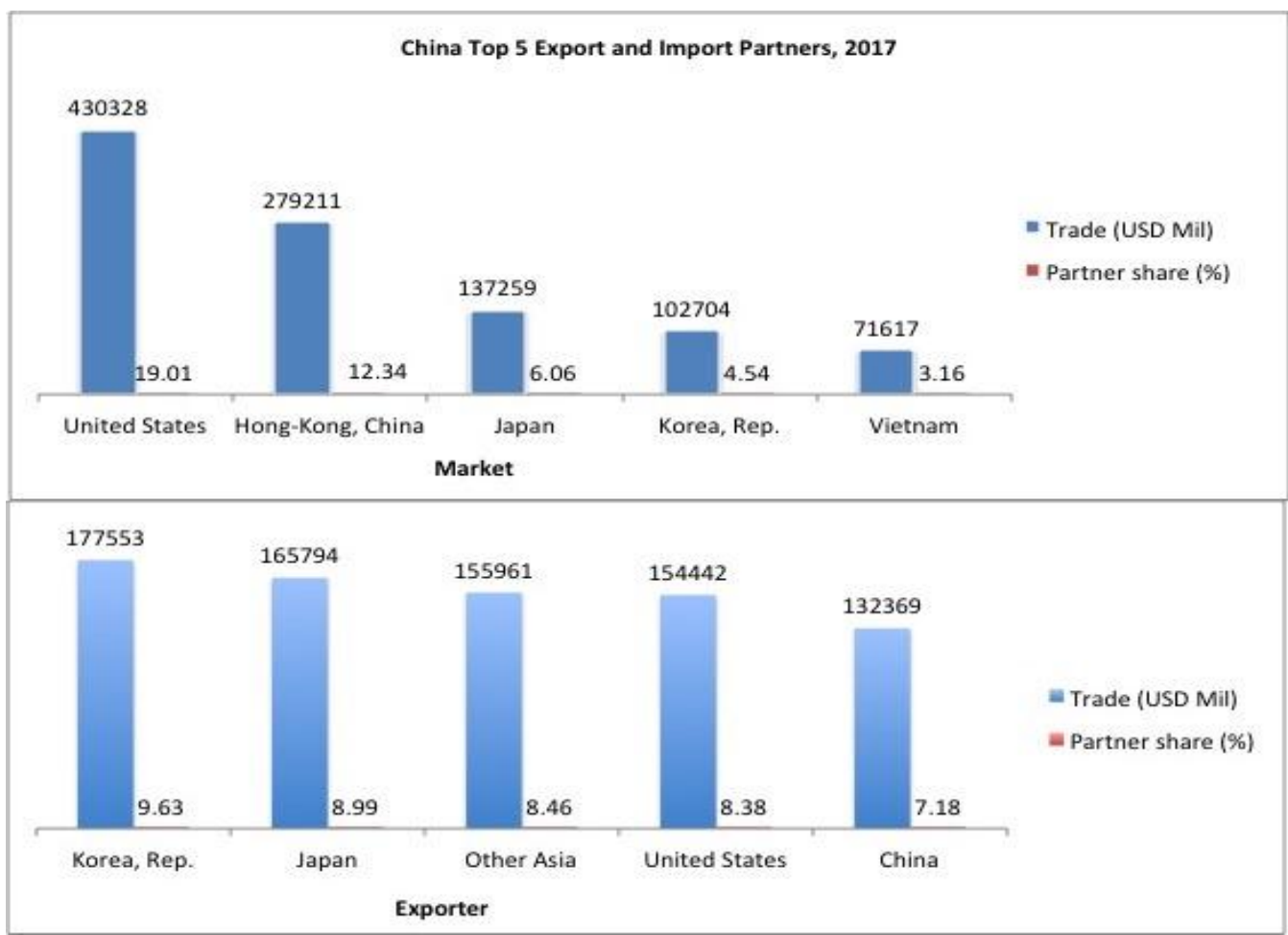

Figure 1. Top trade partners for China, 2017

Source: Data gathered from the WITS webpage

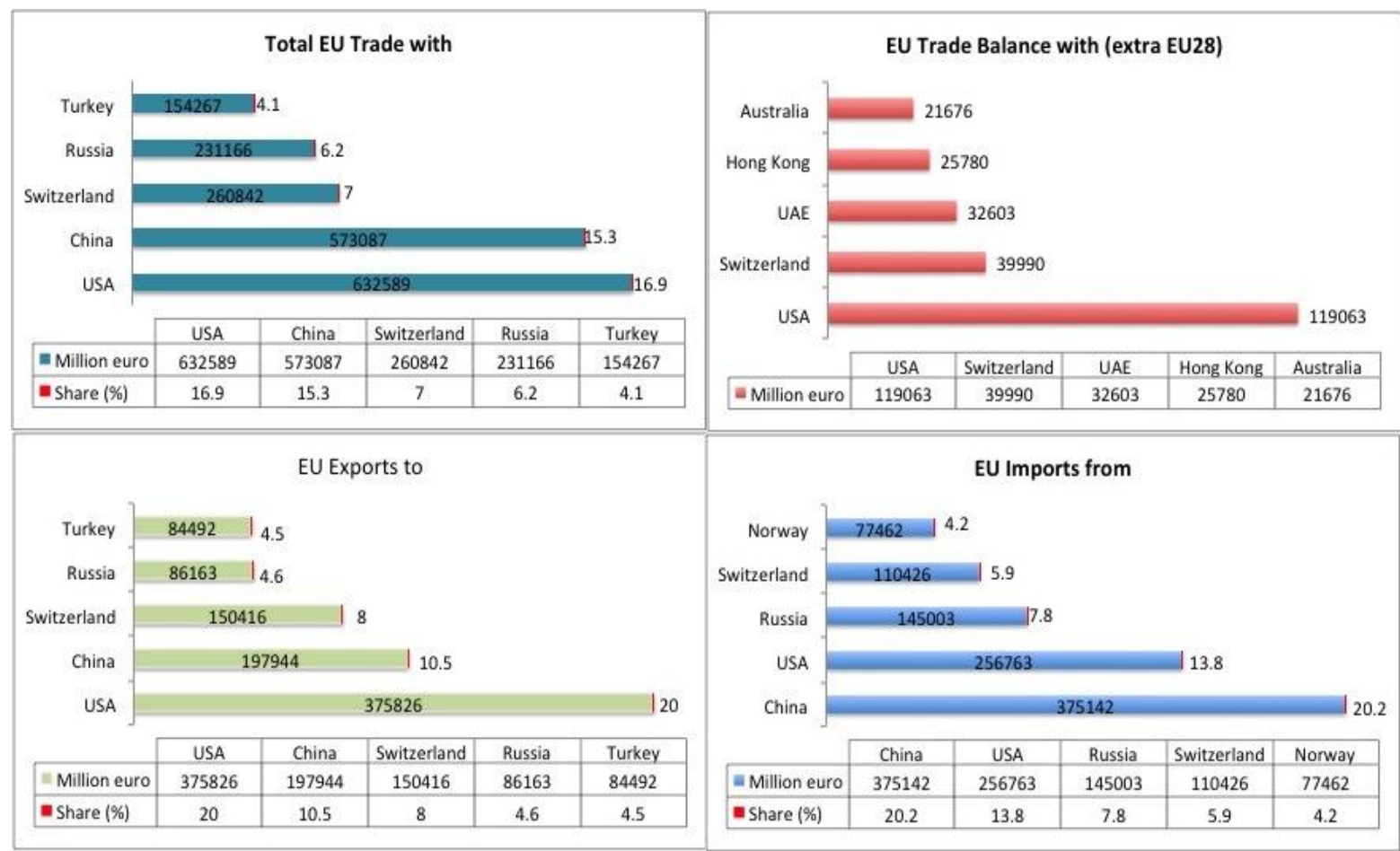

Figure 2. Top 5 Trade Partners for EU extra EU28, 2017

Source: Data gathered from Eurostat and European Commission 
It should be pointed out, that Georgia is on the 38th place among EU trade partners with trade balance in 1333 mln euro. In 2017, EU export to Georgia was $1991 \mathrm{mln}$ euro and import to EU from Georgia 658 mln euro; Total trade with Georgia equals 2649 mln euro (Eurostat).

China is among major trade partners for EU (28 member states). In 2017, the EU imported most goods from China, encompassed 20\% (374.6 bln. euro) of total imports (Figure 3).

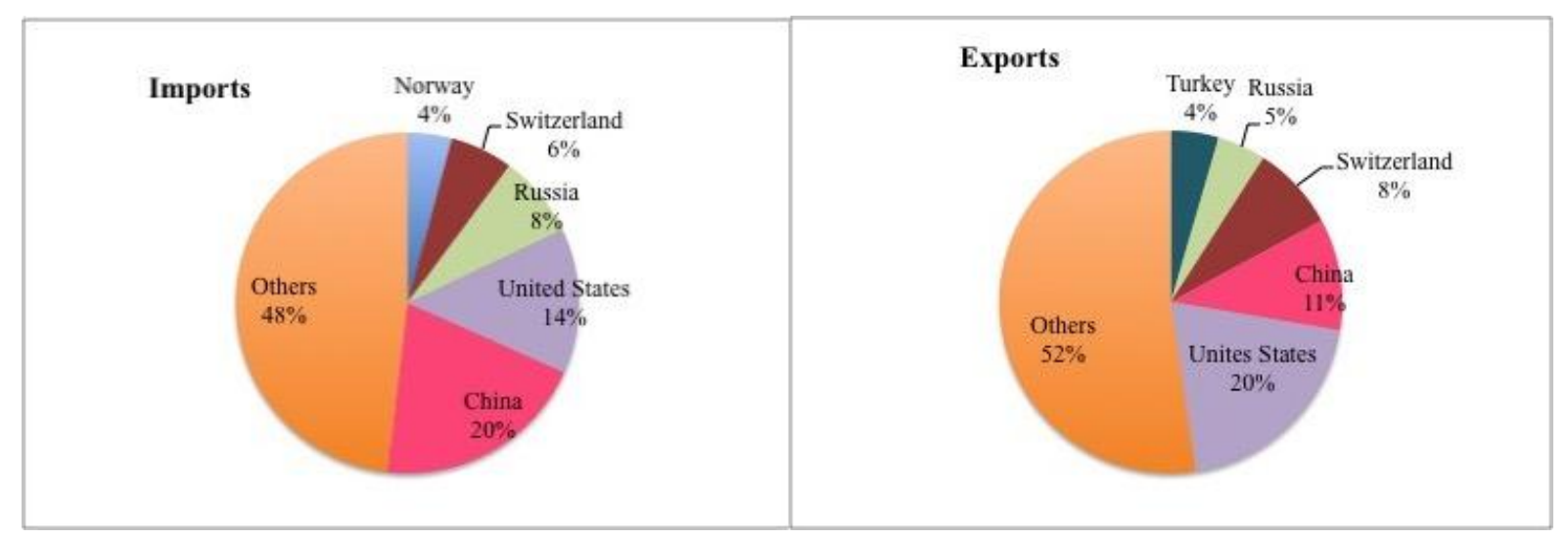

Figure 3. Trade in Goods by Top Five Partners of the EU, 2017

Source: Eurostat,

https://ec.europa.eu/eurostat/web/products-eurostat-news/-/WDN-20180326-1?inheritRedirect=true

Under those circumstances, economic corridors along the BRI have a crucial role for facilitation of the trade between China and EU. There are six trade corridors that OBOR initiative encompasses under the 'belt' initiative. (1) The New Eurasian Land Bridge consists the railway line running from China to Europe through Kazakhstan, Russia, Belarus and Poland. (2) The China-Mongolia-Russia Economic Corridor uses the Trans-Siberian railway. (3) The China-Central Asia-Western Asia Corridor passes through Central Asia to the Mediterranean Sea. The road crosses the South Caucasus over the Caspian Sea omitting Iran to reach Turkey and Europe (corresponding to the Turkish Middle Corridor or TRACECA), and presents an alternative to the Northern options. (4) The China-Pakistan Corridor involves building highway and railway connections all the way through Pakistan to its Gwadar port. (5) The Indo-China Peninsula Corridor (6) The Bangladesh-China-India-Myanmar Corridor (Ramasamy et.al, 2017).

At the present time, the New Eurasian Land Bridge and the China-Mongolia-Russia corridors go into the EU (Inan \& Yayloyan, 2018). Georgia finds its place in one of the corridors, in particular in the Central Asia-West Asia Corridor that aims to connect Asia to Europe in a different way through Turkey and South Caucasus.

Given the increased risks in the modern world, such as natural or man-made disasters, it is important to have transport and energy corridors ensuring the continuity of transport flows. In fact, different economic corridors can substitute one another in critical situations (Charaia \& Papava, 2017). In general there are hardware and software aspects of the corridors, whereas the first involves physical infrastructure, logistics networks, maintenance, and the second includes customs formalities and administrative procedures (De \& Iyengar, 2014). 
In summary, whereas the ancient Silk Road enabled movements of goods and peoples, it also facilitated the economic development of the region it crossed. Nowadays, the corridor approach is meant to influence economic development of nations and regions it traverses. Corridors consider trade and transport, where both logistics infrastructure and services are coordinated to facilitate the flow and storage of goods, people, and information between economic centers. Therefore, technological, organizational, and legal conditions should be improved to support and simplify services. Notably, economic corridors generate investments, and hence can burst economic activities in the region they crossed.

\subsection{The Trans-Caspian Route}

An alternative to the Northern route through Iran is the route passing the South Caucasus over the Caspian Sea to reach Turkey and Europe. According to Inan and Yayloyan (2018), the corridor corresponds to the EU's TRACECA and Turkey's Middle Corridor visions for connecting China to Europe. In 2008, Turkey launched the Silk Road Customs Initiative - the prosecutor for the Middle Corridor, which involved also Georgia, Azerbaijan, Kazakhstan and Kyrgyzstan. According to this 'Caravanserai Project', all these countries work together to ease border crossings, harmonize and simplify customs procedures and reduce border crossing time across the ancient Silk Road (Ministry of Customs and Trade of the Republic of Turkey). Moreover, in 2016, Turkey introduced the "Single Window System in the Customs Services" enabling applicants to submit digital applications for approvals and permissions required for customs to a single contact point. Consequently, this integrated management system between related institutions and organizations reduces time and costs in customs operations (Ministry of Customs and Trade of the Republic of Turkey). It is certainly noteworthy that this is the preferred route of the Turkish government; but it also is a critical priority for countries in the South Caucasus. From a EU perspective, the Trans-Caspian corridor has the advantage of promoting Chinese-EU trade as well as promoting EU's access to energy markets in Central Asia avoiding its dependency on Russia, primarily in energy. The EU has established good political relations with countries along the Middle Corridor (Inan \& Yayloyan, 2018).

As a multimodal route, the Trans-Caspian route or the Middle Corridor involves crossing several countries between China and Europe, and therefore, it requires a comprehensive network of infrastructure, harmonized customs and simplified cross-border procedures. However, according to the research, the corridor is still underused, and underinvested, as China's east-west land trade to Europe largely focuses on the Northern routes (Inan \& Yayloyan, 2018). Nevertheless, the Trans-Caspian route may become an alternative route as in 2017, the International Association of the Trans-Caspian International Transport Route (TITR) signed a memorandum of cooperation with the China Communications and Transportation Association in a meeting attended by 80 representatives of railway departments, port, shipping and logistics companies from Kazakhstan, China, Ukraine, Poland, Turkey, Azerbaijan, Georgia, Lithuania and Latvia (Israfilbayova, 2017).

One of the most significant parts of the Trans-Caspian route is the Baku-Tbilisi-Kars 826-km railway project - 'Silk Road', which has a capacity to transport 1 million passengers and 6.5 million tons of cargo per year, with potential to reach 3 million passengers and 17 million 


\section{Macrothink}

Business and Economic Research

ISSN 2162-4860

2019, Vol. 9, No. 1

tons of cargo by 2034 (Ministry of Transport and Infrastructure of the Republic of Turkey; Turp, 2017).

Although the Baku-Tbilisi-Kars railway has been officially completed, Turkey lacks an effective railway network linking Kars to western Turkey and then to the EU. Moreover, poorly connected ports to their hinterlands in Turkey impede the flow of trade from Georgia via Turkey to Europe (Inan \& Yayloyan, 2018).

The Trans-Caspian International Transport Route starts from Southeast Asia and China runs through Kazakhstan, the Caspian sea, Azerbaijan, Georgia and further to European countries (Map 1). Trains over this route are expected to reach Istanbul, Turkey in 14-15 days (TITR Website).

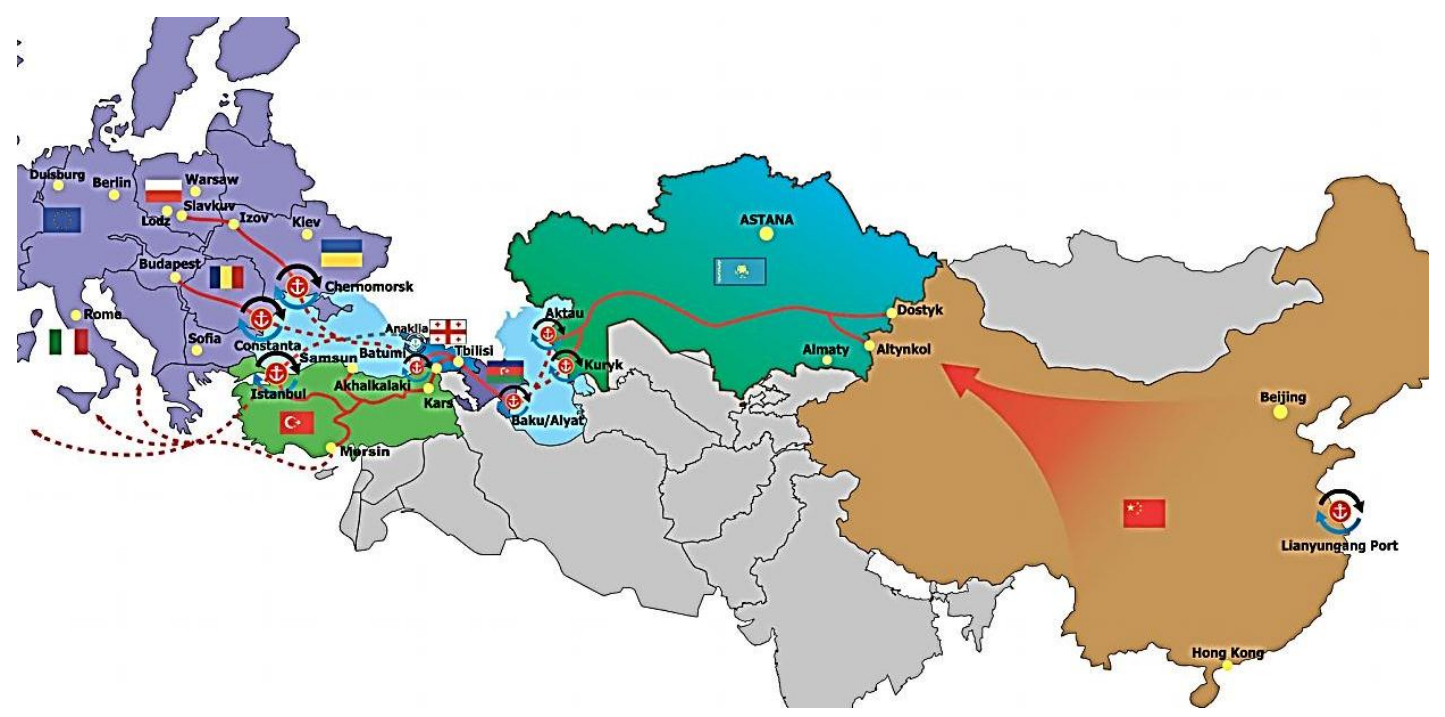

Map 1. Trans-Caspian International Transport Route

Source: TITR Webpage - http://titr.kz/en/route

\subsection{Presence of China in the South Caucasus under the OBOR}

Currently, Chinese involvement is relatively modest in the South Caucasus. Expectations from Chinese presence include investments in economic development and more importantly an inflow of Chinese capital, especially in the infrastructure projects connecting the Middle Corridor consisting of roads, railways and ports (Inan \& Yayloyan, 2018).

A precursor of China with its New Silk Road Initiative was The US - an extra-regional actor presaging Chinese One Belt One Road. The New Silk Road Initiative, announced by Secretary of State in 2011, represented a vision for fostering regional development and trade, taking Afghanistan as its starting point. However, the US effort never really took off due to security concerns in Afghanistan and Pakistan (Inan \& Yayloyan, 2018).

On the other hand, Russia remains an influential economic actor both in the South Caucasus and in Central Asia, where its presence lasted about 70 years before the downfall of the Soviet Union. 


\section{Macrothink}

It should be noted, that China also focuses on the energy sector in the Caspian Sea oil and gas resources. Markedly, the region's geopolitical importance is attested by the presence of gas and oil reserves in the Caspian Sea and in Central Asia as well as pipelines crossing the region to Europe. While the economic cooperation between Turkey, Azerbaijan, and Georgia is strong, Armenia is left out because of the strained relations with both Azerbaijan and Turkey. However, Armenia uses the trade route that traverses Georgia (Inan \& Yayloyan, 2018). Likewise Turkey has a free trade agreement with Georgia, but not with Azerbaijan. There is competition in the region to be a transit route for cargos, so Georgia needs to find its competitive advantage to benefit from the corridor.

In the region, Turkey has the largest economy with GDP USD 851.10 billion in 2017, when its total exports were USD 157 billion compared to USD 16.5 billion, USD 2.3 billion, and USD 2.25 billion for Azerbaijan, Georgia and Armenia, respectively (WTEx; Statista). In 2016, China was the 3rd largest trade partner for Georgia after Turkey and Russian Federation, whereas China was a major import partner for Armenia, Azerbaijan, and Turkey (Figure 4). 


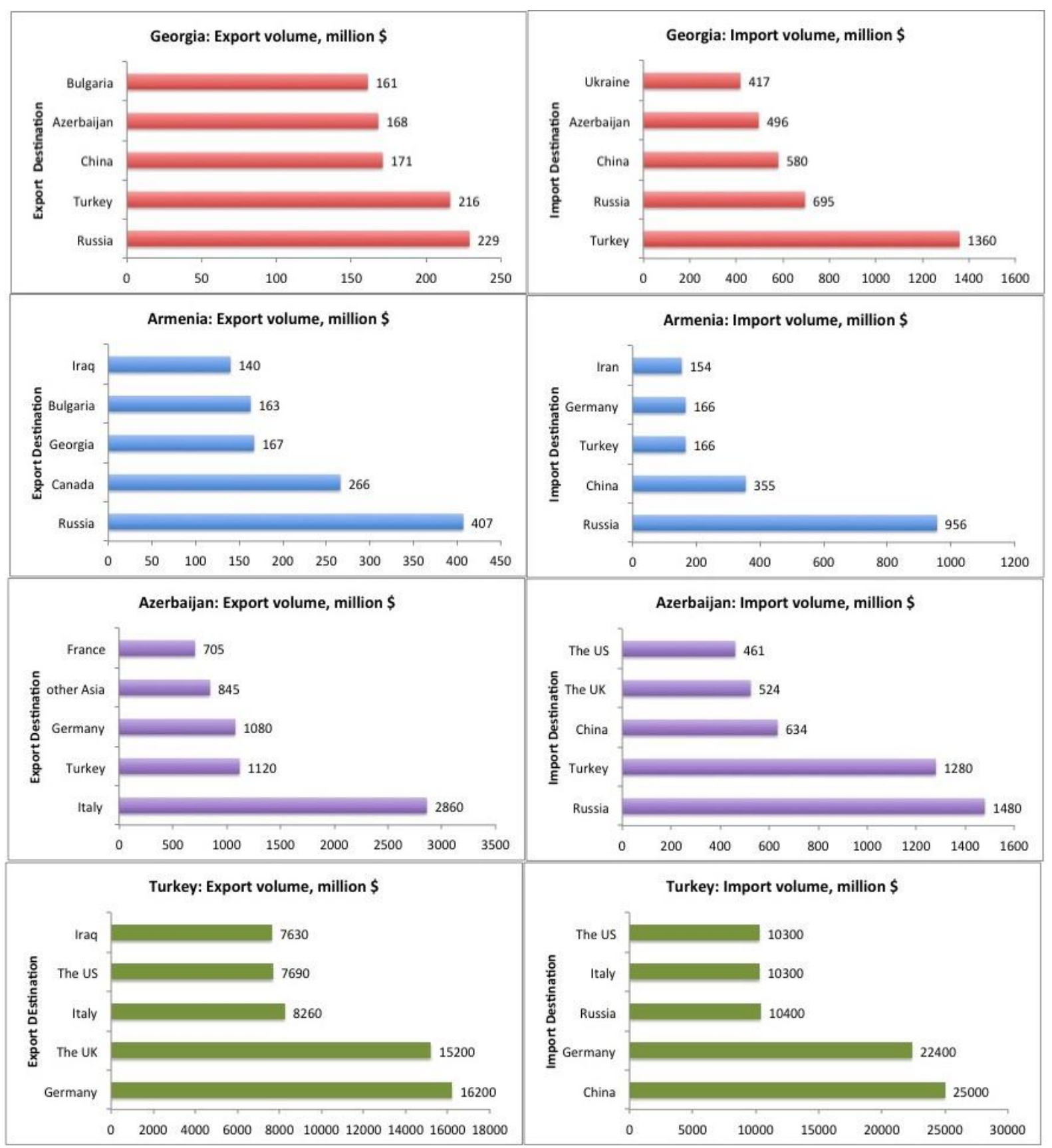

Figure 4. Top 5 Export and Import Partners for Georgia, Armenia, Azerbaijan, and Turkey, 2016

Source: Data have been gathered from the OEC webpage.

The data changed slightly in 2017, when China was among the largest trade partners for Armenia, Azerbaijan, and Turkey with export trade in USD 466 million, USD 978 million, and USD 23.371 billion correspondingly. In Comparison with 2016, the trade volume has considerably increased. In addition, import trade has also augmented from European countries into the South Caucasus. Bulgaria, Switzerland and Germany are among key import partners for Armenia, while main import markets for Azerbaijan are Italy and Czech Republic; besides, Germany is the biggest import market for Turkey (Table 1). 
The Middle Corridor is important for Turkey for two main reasons. First, its access to export markets largely depends on geography. Further, the corridor offers an opportunity for development the country's underdeveloped region it is crossing.

Table 1. Top Trade Partners for Armenia, Azerbaijan, and Turkey, 2017

\begin{tabular}{|c|c|c|c|c|c|c|}
\hline \multicolumn{4}{|c|}{ Top 5 Export Partners, 2017} & \multicolumn{3}{|c|}{ Top 5 Import Partners, 2017} \\
\hline Country & Exporter & $\begin{array}{l}\text { Trade } \\
\text { (mln. USD) }\end{array}$ & $\begin{array}{l}\text { Partner } \\
\text { Share (\%) }\end{array}$ & $\begin{array}{l}\text { Import } \\
\text { Market }\end{array}$ & $\begin{array}{l}\text { Trade } \\
\text { (mln. USD) }\end{array}$ & $\begin{array}{l}\text { Partner } \\
\text { Share }(\%)\end{array}$ \\
\hline \multirow{5}{*}{ Armenia } & 1. Russia & 1166 & 29.94 & 1. Russia & 541 & 25.20 \\
\hline & 2. China & 466 & 11.96 & 2. Bulgaria & 282 & 13.13 \\
\hline & 3. Turkey & 222 & 5.69 & 3.Switzerland & 246 & 11.49 \\
\hline & 4. Iran & 174 & 4.48 & 4. Georgia & 145 & 6.76 \\
\hline & 5. Germany & 164 & 4.22 & 5. Germany & 127 & 5.92 \\
\hline \multirow{5}{*}{ Azerbaijan } & 1. Russia & 1471 & 16.78 & 1. Italy & 4406 & 31.94 \\
\hline & 2. Turkey & 1285 & 14.66 & 2.Turkey & 1366 & 9.90 \\
\hline & 3. China & 978 & 11.16 & 3. Israel & 639 & 4.63 \\
\hline & 4. The US & 729 & 8.32 & 4. Russia & 587 & 4.25 \\
\hline & 5. Ukraine & 483 & 5.51 & 5.Czech Rep. & 557 & 4.04 \\
\hline \multirow{5}{*}{ Turkey } & 1. China & 23371 & 10.00 & 1. Germany & 15119 & 9.63 \\
\hline & 2. Germany & 21302 & 9.11 & 2. The UK & 9603 & 6.12 \\
\hline & 3. Russia n & 19514 & 8.35 & 3. The UAE & 9184 & 5.85 \\
\hline & 4. The US & 11952 & 5.11 & 4. Iraq & 9055 & 5.77 \\
\hline & 5. Italy & 11305 & 4.84 & 5. The US & 8655 & 5.51 \\
\hline
\end{tabular}

Source: Data gathered from the WITS Webpage

However, Georgia is still among the main trade partners only for Armenia. Moreover, key trade partners for Georgia are its close neighbors - Turkey and Russia with export trade in USD 1373 million and USD 789 million, respectively, as well as China with partner shares $9.18 \%$ in export trade. However, China ranked fifth in the import trade for Georgia with USD 207 million, after its immediate neighbor countries. Russia is still a major trade partner in spite of strained relationships between two countries (Figure 5). This finding confirms that geographical proximity of markets and the availability of transport connections play crucial role in trade. Yet, close economic ties with a country of tremendous economic capabilities are definitely in Georgia's interests in order to diversify export markets and attract foreign investment. 


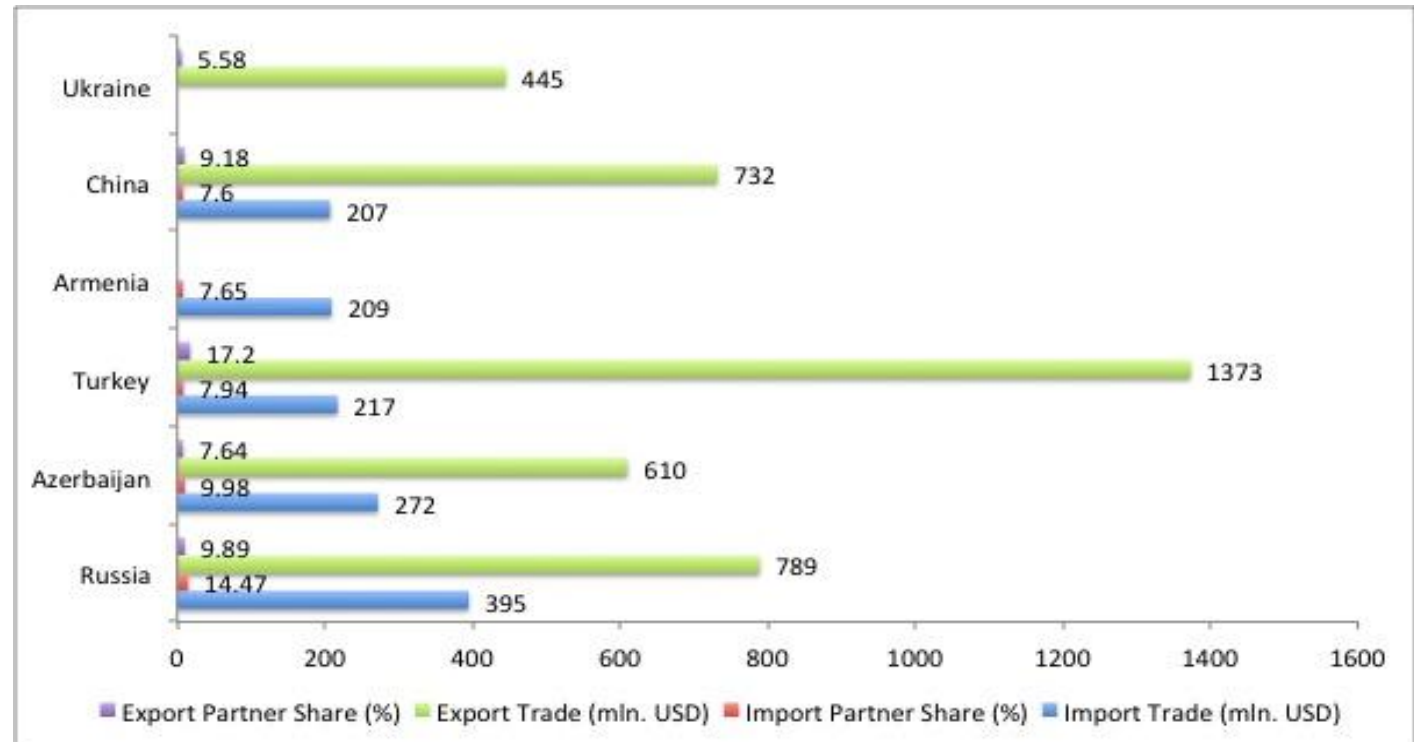

Figure 5. Top Trade Partners for Georgia in 2017

Source: Data gathered from the WITS Webpage

Although Georgia's economic weight is significantly smaller but growing, the country has an important role in the South Caucasus as a transit country for trade flows and energy projects. The EU (28) is Georgia's trading partner along with Turkey, China, and Russia. Over the past decade, Georgia has increased its cooperation and hence bilateral trade with China. Now China is its third largest trade partner (Figure 6). This partnership has been as well promoting by the free trade agreement between China and Georgia signed in 2017. Furthermore, Georgia hopes to expand its exports, especially in beverages, to China (Inan \& Yayloyan, 2018) as well as to the European countries.

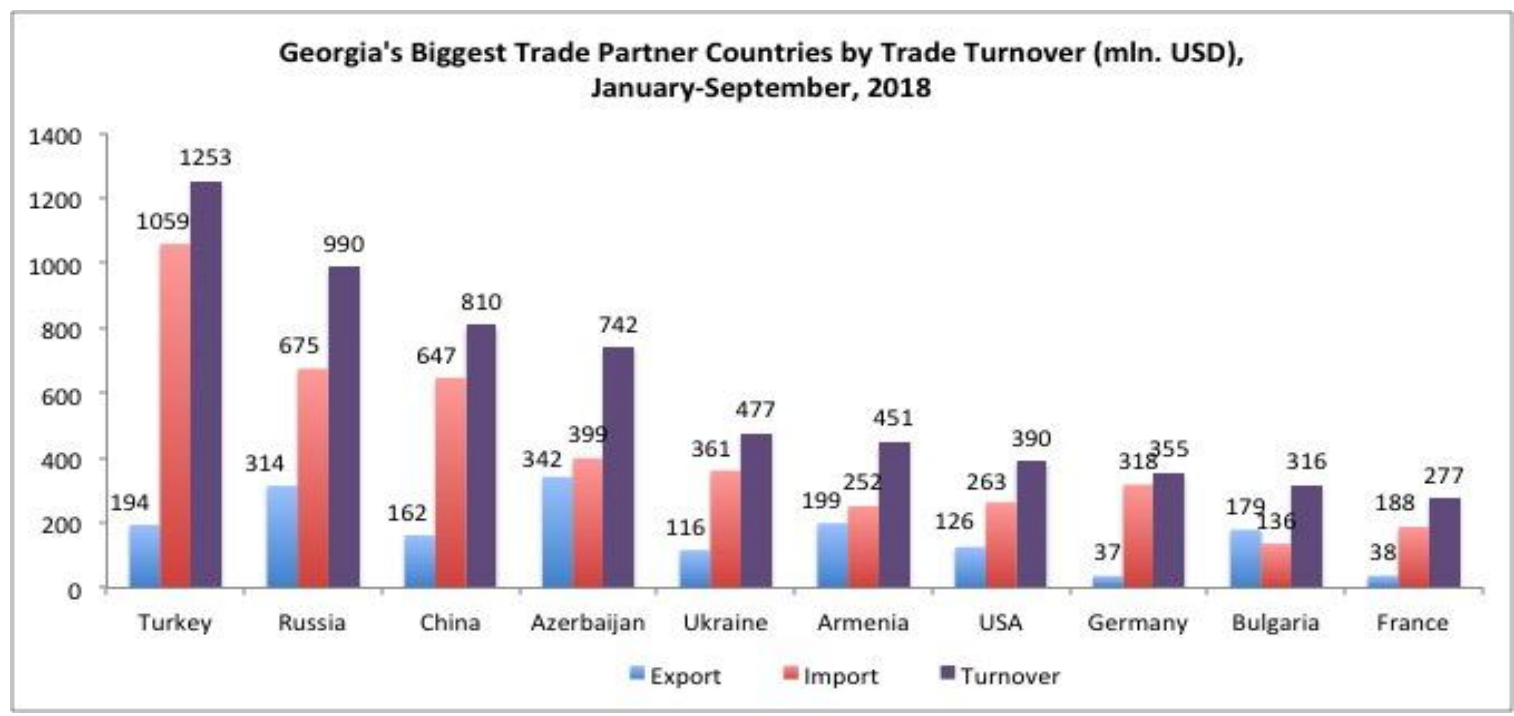

Figure 6. Georgia's Biggest Trade Partners by Trade Turnover, mln. USD, Jan.-Sept. 2018

Source: Ministry of Economy and Sustainable Development of Georgia. 
In Georgia, China is interested in the country's ports for trade connections across the Black Sea. Besides, Georgia's Association Agreement with the EU is an additional point for attraction. Chinese investors can link with the EU and other markets through Georgia. On the other hand, Georgia also considers good relations with China as a possible counterweight to Russia's dominance in the region (Inan \& Yayloyan, 2018). Nevertheless, China's presence in Georgia, while growing, is still limited. Chinese actors have shown interest in carrying out projects in different countries along the routs that may benefit the trans-Caspian connection. Chinese company Hualing group - Georgia's largest foreign investor established a Free Industrialized Zone in Kutaisi, which is near the Anaklia Deep Water Sea Port projected to transport Chinese goods to Europe (Larsen, 2017). Hualing invested USD 40 million in the Zone, which is expected to handle 40 million tons of cargo annually (Hualing Group Website). Likewise, the China Energy Company Limited (CEFC) purchased 75\% of shares in the Poti Free Industrial Zone located in the Poti port (Inan \& Yayloyan). In the energy sector, the Chinese state-owned enterprise, Dongfang Electric, in 2015 pledged USD 180-USD 200 million for the construction of thermal power plant (150 megawatt) in western Georgia, the Tkibuli region (Van Dijk \& Martens, 2016). In addition to investing in free economic zones in Georgia, Chinese companies are also investing in infrastructure, energy, mining, healthcare, finance and agriculture sectors (Larsen, 2017).

Thus, Georgia aims to become a transit hub of trade between China and Europe under the framework of the BRI that focuses on connectivity and cooperation between Eurasian countries. In effect, its position in the Black Sea ports - Batumi, Poti, and Anaklia can turn the country to the logistics hub in the region, and compete with the Black Sea ports in eastern Turkey, which are unfinished. Moreover, Turkey's internal rail network is not yet developed to carry goods travelling on the east-west Silk Road from Kars (Inan \& Yayloyan). In the long term, Anaklia Deep Sea Port can improve the overall competitiveness of Georgia as a transit hub.

From the Chinese perspective, two valuable projects in the South Caucasus are related to Georgia: the Baku-Tbilisi-Kars railroad making it possible to deliver containers, freight and passengers from Asia to Europe 45\% faster; and Expanding the East-West Highway, Georgia's main land road transport. Over the past years, trade between China and Georgia has been extended significantly (Figure 5). The trade turnover between two countries has been increasing almost every year, which is especially important for Georgia because of its growing export production such as wine and other alcoholic beverages to China (Charaia \& Papava, 2017). Obviously, the free trade agreement with China will stimulate the export potential of Georgian companies. 


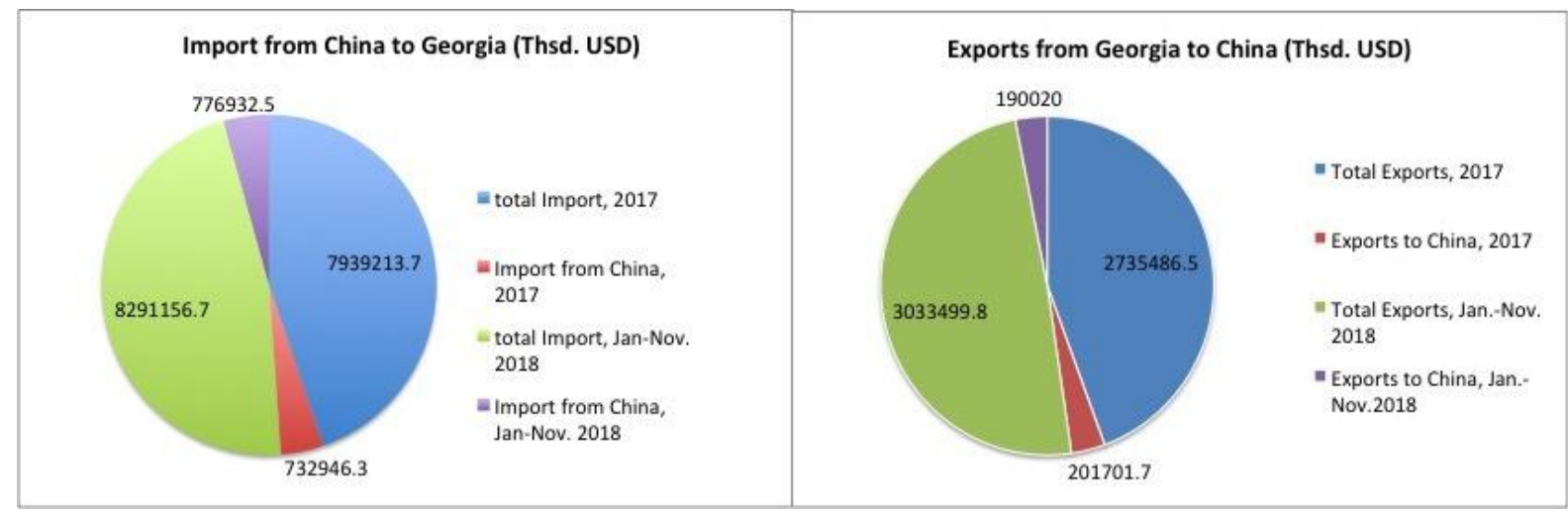

Figure 7. Trade Volume between China and Georgia (Thsd. USD)

Source: Data gathered from the Geostat Webpage

Similarly, China is third largest investor in the Georgian economy. Chinese company Hualing Group has made an approximate US\$500 million investment in Georgia since 2007 (Tskhovrebova, 2016). Specifically, Foreign Direct Investment flows from China to Georgia have been increasing since 2011 (Figure 8).

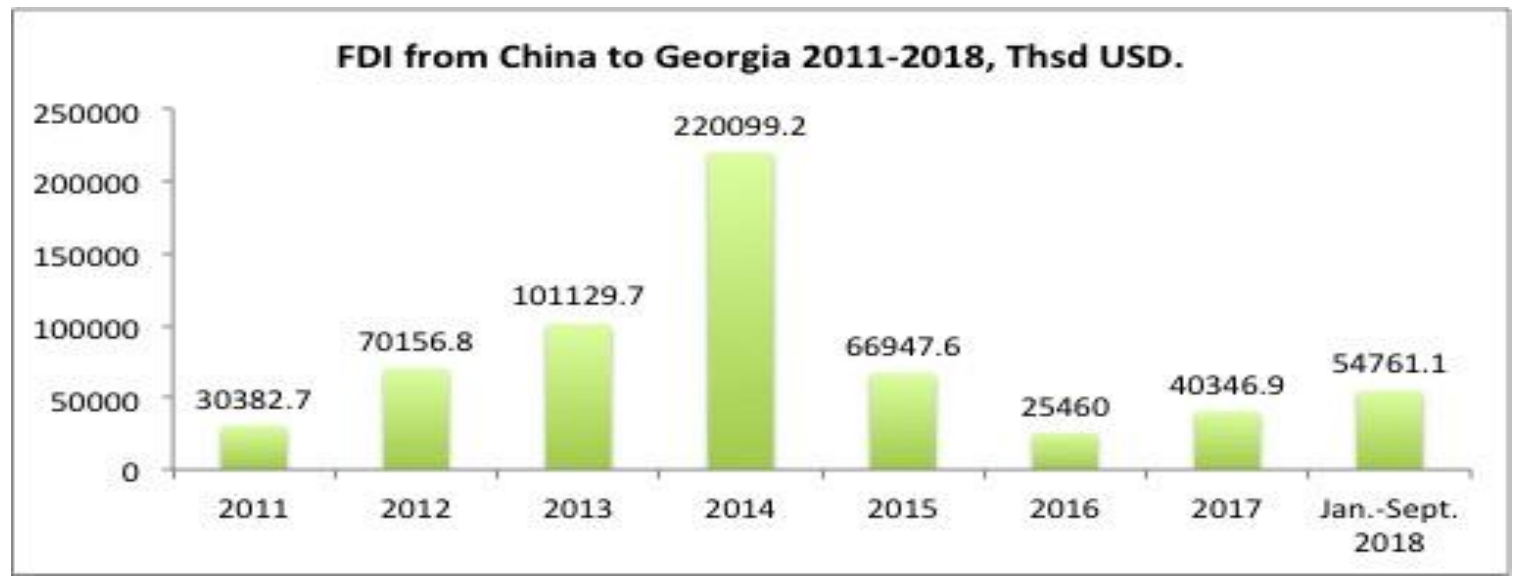

Figure 8. FDI from China to Georgia 2011-2018, Thsd USD

Source: Data gathered from the Geostat Webpage

Among the major source countries for FDI into Georgia are Azerbaijan with USD 465 million and Netherlands investing more than USD 356 million in 2017. The largest investment from the United Kingdom was made in 2015, while the biggest FDI from the United States - USD $184.7 \mathrm{mln}$. was invested in 2014. FDI from the Czech Republic has steady augmented since 2011 (Table 2). 
Table 2. Foreign Direct Investment inflow volume into Georgia, Top Countries, Million USD, 2013-2017

\begin{tabular}{|l|l|l|l|l|l|}
\hline & 2013 & 2014 & 2015 & 2016 & 2017 \\
\hline Total & $\mathbf{1 0 2 0 . 5}$ & $\mathbf{1 8 1 7 . 7}$ & $\mathbf{1 6 6 5 . 6}$ & $\mathbf{1 5 6 5 . 8}$ & $\mathbf{1 8 8 8 . 8}$ \\
\hline Among them: \\
\hline Azerbaijan & 84.6 & 340.5 & 581.6 & 558.5 & 465.0 \\
\hline Netherlands & 158.2 & 376.8 & 158.5 & 72.3 & 356.7 \\
\hline Turkey & 51.4 & 73.9 & 74.6 & 209.8 & 286.3 \\
\hline The UK & 55.2 & 108.9 & 398.8 & 103.0 & 248.9 \\
\hline Czech Rep. & 43.6 & 52.0 & 16.7 & 87.0 & 142.5 \\
\hline The USA & 44.8 & 184.7 & 20.7 & 58.4 & 79.7 \\
\hline Luxemburg & 91.7 & 109.6 & 106.0 & 88.8 & 68.3 \\
\hline UAE & 63.7 & 4.4 & 8.2 & -6.8 & 57.8 \\
\hline Panama & 25.8 & 70.7 & 9.5 & 75.9 & 52.8 \\
\hline China & 101.1 & 220.1 & 66.9 & 25.5 & 40.3 \\
\hline Other countries & 300.4 & 276.2 & 224.0 & 293.6 & 90.4 \\
\hline
\end{tabular}

Source: Geostat

It should be pointed out that the Netherlands ranked number one investor country of Georgia by FDI volume in 3rd quarter of 2018. Other European countries from where Georgia has attracted direct investments are Luxemburg, and France (Figure 9).

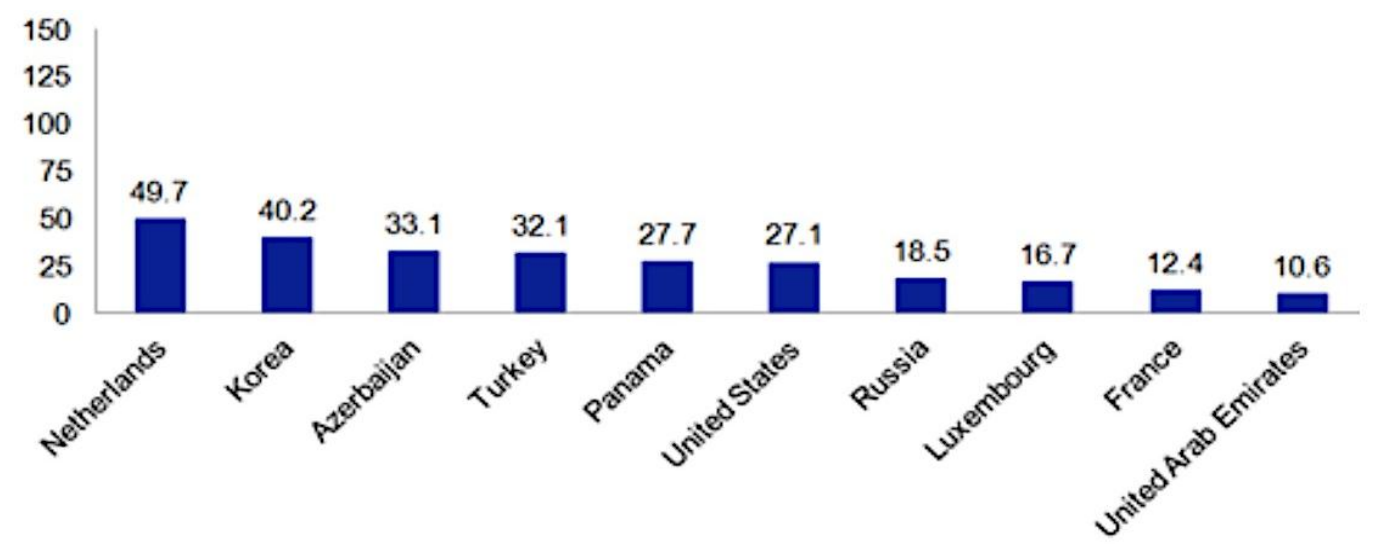

Figure 9. Foreign Direct Investments in Georgia by Countries, 3rd Quarter 2018, Million USD

Source: Geostat

Furthermore, Turkey with its geostrategic position in the middle of energy transit routes aspires to reap the benefits as a logistics hub in the region, and attracts investments from China. Simultaneously, Turkish investments are significantly in markets in the South Caucasus. Nowadays, the Turkish port of Ceyhan has become an important hub for Caspian oil exports passing through the Baku-Tbilisi-Ceyhan Oil Pipeline (Inan \& Yayloyan, 2018).

Turkey, Azerbaijan, and Georgia are cooperating through three mega projects in transportation and energy sectors: (1) Baku-Tbilisi-Ceyhan (BTC) oil pipeline serves as 
Azerbaijan's main export pipeline rising above the Baku-Supsa (via Georgia) and Baku-Novorossiysk (via Russia) pipelines. Besides, key energy suppliers in Central Asia such as crude oil from Kazakhstan and Turkmenistan are also transported through BTC; (2) the Baku-Tbilisi-Erzurum (BTE) or the South Caucasus Pipeline (SCP) connects Azerbaijani Shaz-Deniz fields with Erzurum in Turkey over Georgia. And the EU proposed Trans-Caspian gas pipeline connects the BTE to producers in Turkmenistan and Kazakhstan (Denoon, 2015); (3) the Baku-Tbilisi-Kars railway links the Trans-Kaspian connection reaching out to markets in Turkmenistan and in Kazakhstan and further into Asia to China. It has potential to transport 1 million passengers and 5 million tons of freight per year (Iron Silk Road Webpage); by 2030 the capacity is estimated to reach 3 million passengers and 17 million tons cargo (Railway Technology Webpage). Azerbaijan is a main investor in this railway scheme also making a loan of $\$ 770$ million to Georgia for the construction rehabilitation of the routes through Georgia (Valiyev, 2016).

Whereas Turkey has considerable presence both in the South Caucasus and in Central Asian countries giving an incentive to regional economic projects, Azerbaijan seeks to establish a balance in its relations with the EU and Russia (Inan \& Yayloyan, 2018). Azerbaijan, possessing oil and gas reserves, is a major player in energy projects that look west to Europe through the BTC oil pipeline, and the BTE gas pipeline. More than half of Azerbaijan's energy exports go to the EU(28). Azerbaijan supports the EU proposition for a trans-Caspian gas pipeline to connect the BTE to producers in Turkmenistan and Kazakhstan (Denoon, 2015). Given that Azerbaijan's energy resources are limited, this project is important for the country to maintain its stature in the region. Thus, Azerbaijan is investing in positioning itself as a transit hub (Valiyev, 2016). Additionally, major Chinese cellular and telecommunication companies are also investing in the country (Inan \& Yayloyan, 2018).

In comparison with the other countries in the South Caucasus, Armenia has limited economic interactions with trade and transport connections, as it is a landlocked country. Currently, Armenia's borders with Azerbaijan and Turkey are closed, while the other two borders with Georgia to its north and Iran to its south are open. Russia is Armenia's top import partner and dependent on its gas. All trade to Armenia goes through Georgia offering the country a trade opening (Inan \& Yayloyan, 2018).

The increased trade along the Middle Corridor can also affect Armenia providing connections and investments it desires. Besides, as a member of the Eurasian Economic Union (EAEU), and having access to the market of 180 million, the country can also attract investments from China. However, Chinese interest in Armenia at the moment is more geo-political than economic. Presently, Armenia is looking to enhance its links through a North-South corridor involving India, Iran and Georgia (Inan \& Yayloyan, 2018). Furthermore, Armenia was a key hub for software development, industrial computing, electronics, and for the manufacturing of semiconductors during the Soviet period and ICT remains one of the fastest-growing sectors of Armenia's economy (Enterprise Incubator Foundation, 2017).

In addition, a gravity model has been built for Armenia, Azerbaijan, China, Georgia, and Turkey, included 20 years period from 1996 to 2016 for dependent variable set In(trade $\operatorname{tij}_{\mathrm{ij}}$, and 


\section{Ml Macrothink}

Business and Economic Research

ISSN 2162-4860 2019, Vol. 9, No. 1

independent variables such as tariffs, distance, GDP (Figure 10). The data have been collected from ESCAP Trade Analytics Portal (https://trade.unescap.org/analytics).

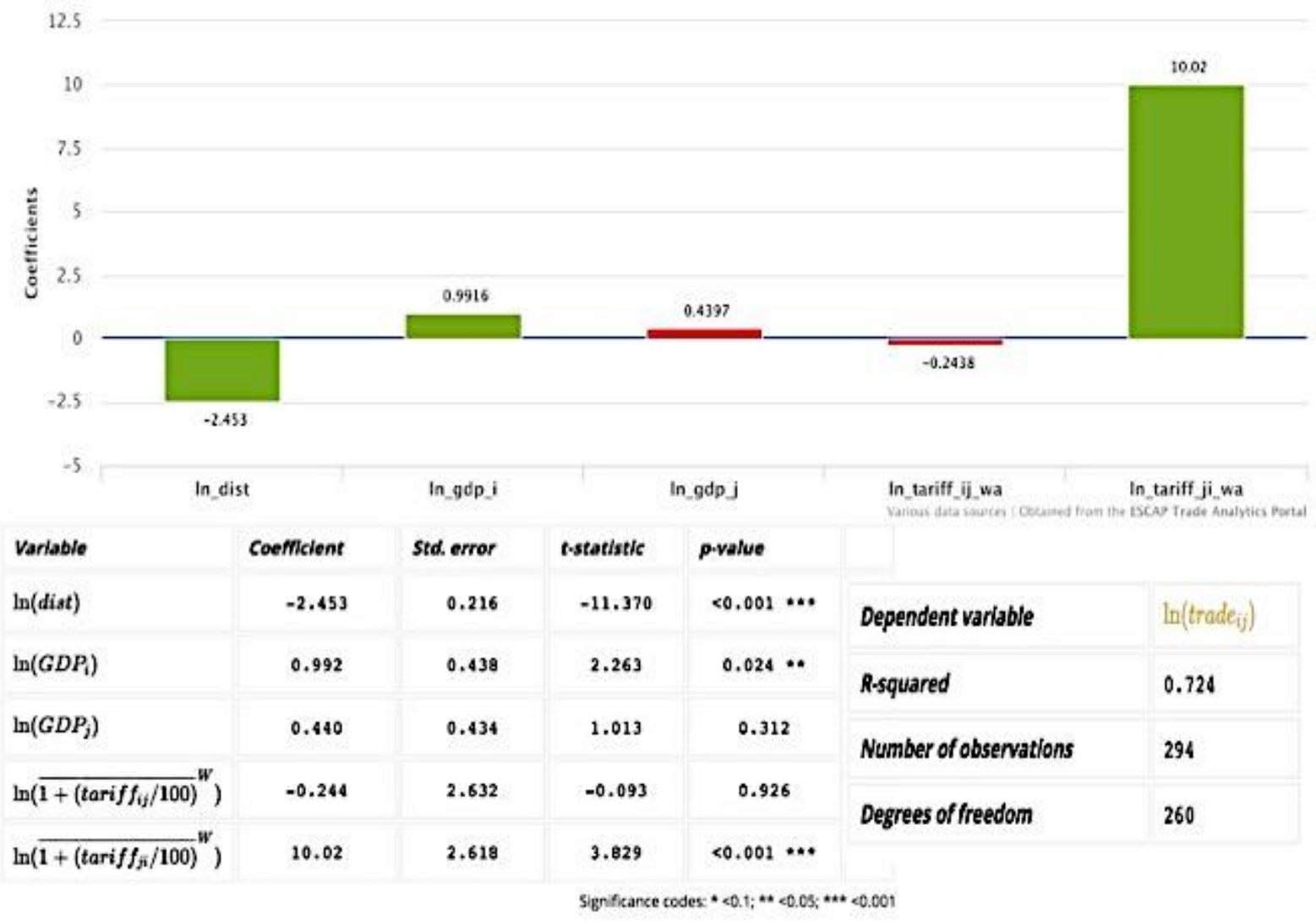

Figure 10. Regression Results of In(tradeij) of 5 countries.

Moreover, a basic gravity model demonstrated trade potential of Georgia with Armenia, Azerbaijan, and China, in 2016 (Table 3).

Table 3. Trade potential results for dependent variable In(tradeij) of Georgia

\begin{tabular}{|c|c|c|c|}
\hline Partner & $\ln \left(\right.$ trade $\left._{i j}\right)$ & $\ln \left(\widehat{\operatorname{trad}}_{i j}\right)$ & Estimated to actual trade ratio \\
\hline Armenia & 19.459 & 18.487 & 0.950 \\
\hline Azerbaijan & 20.127 & 19.046 & 0.946 \\
\hline China & 20.389 & 20.819 & 1.021 \\
\hline
\end{tabular}

Thus, although Armenia does not belong to the Trans-Caspian initiative, it is still part of BRI, subsequently it will derive economic benefits from the development of the region due to FDI or the Middle Corridor.

To summarize, China and the EU have economic connections with the countries in the South Caucasus and with Turkey. Moreover, Russia's role is also influential in the South Caucasus, so the countries consider Chinese investments to rebalance these interests. Furthermore, trade can flourish through improved connectivity under the BRI, and investments can be attracted, 
which will facilitate economic growth of all states in the South Caucasus.

\section{Opportunities Created by OBOR for Georgia}

The research question this chapter addresses is in what extent the OBOR can benefit Georgia.

Obviously, Georgia has the political will and determination to be part of the Belt and Road Initiative that includes six trade corridors, one of which (China-Central Asia-West Asia) covers the TRACECA and connects China through Kazakhstan, Azerbaijan, Georgia, and Turkey - to Europe. This very corridor offers various opportunities to Georgia by utilizing its strategic location as well as business-friendly environment. The country has been consistently ranked high in the areas of doing business and economic freedom, has low rates of corruption, and in general, enjoys liberal trade policy. Thus, these advantages can attract more foreign investments, and create favorable conditions also by improved connectivity to encourage trade. Since success and sustainability of the BRI depends on the business interests, initiatives of private entities along the corridors would be welcomed.

Furthermore, Georgia has a favorable geographic location, situated between Europe, Turkey and China, combined with a friendly business environment and strong political will to act as a logistics hub to bridge Asia with Europe. However, there are competing interests of China's Silk Road Economic Belt and Russia's Eurasian Economic Union initiative aimed at bringing former Soviet states into a single economic space (Bond, 2016). For this reason, Georgia needs to use the visible window of opportunity despite the external factors by determining how to become more than just a transit country. Specifically, it should develop a coherent, coordinated and complementary strategy based on national interests and reflective of the comparative advantage of different development and strategic partners (Pantucci \& Lain, 2016).

Historically, Georgia due to its location among empires, which shaped its geopolitical position, especially since the downfall of Soviet Union, has tried to balance interests of powers in the region. All big players such as Russia, Turkey, the EU, the US, Iran, or Azerbaijan have their own interests in the South Caucasus, but also China has been gaining strength as another power with its BRI.

Moreover, Georgia as the most westernized country in the region has advanced position both politically and economically. In this regard, its strategic geographical position can be transformed in economic opportunities not only for Georgia but also for China. Today, Georgia has free trade regime with all CIS countries, Turkey, European Union, Peoples Republic of China and European Free Trade Association (EFTA). The Association Agreement including Deep and Comprehensive Free Trade Agreement, and FTA signed with EFTA countries gives Georgian products duty free access to markets of the EU28 as well as to those of Iceland, Liechtenstein, Norway, and Switzerland. General Schemes of Preference for Georgia with the US, Canada, and Japan have also been applied for, with the result being lower tariffs on 3400 goods exported from Georgia. Additionally, Georgia is a member of the World Trade Organization (WTO) since 2000 (Ministry of Economy and Sustainable Development of Georgia). Furthermore, Georgia's liberal trade regimes provide investors 


\section{Macrothink}

Business and Economic Research

ISSN 2162-4860 2019, Vol. 9, No. 1

with a favorable opportunity to access the 900 million markets without customs duty; besides, the average time for customs clearance is currently about 15 minutes (Georgian National Investment Agency).

Despite Georgia's small economy and lack of natural resources, it can be an attractive partner for China for several reasons. First, it has a strategic location for the BRI, and second, the country is considered as a political stable, corruption-free investment destination with low business costs, but also because of its improved business environment (Georgian National Investment Agency). Business-friendly environment of Georgia is expressed in the indices in 2018 and 2019 (Figures 11-12). Georgia ranked 2nd on the ease of starting a business, and 6th on doing business (Figure 11). Moreover, it graded 16th in the world in the Economic Freedom Index in 2018 (Figure 12).

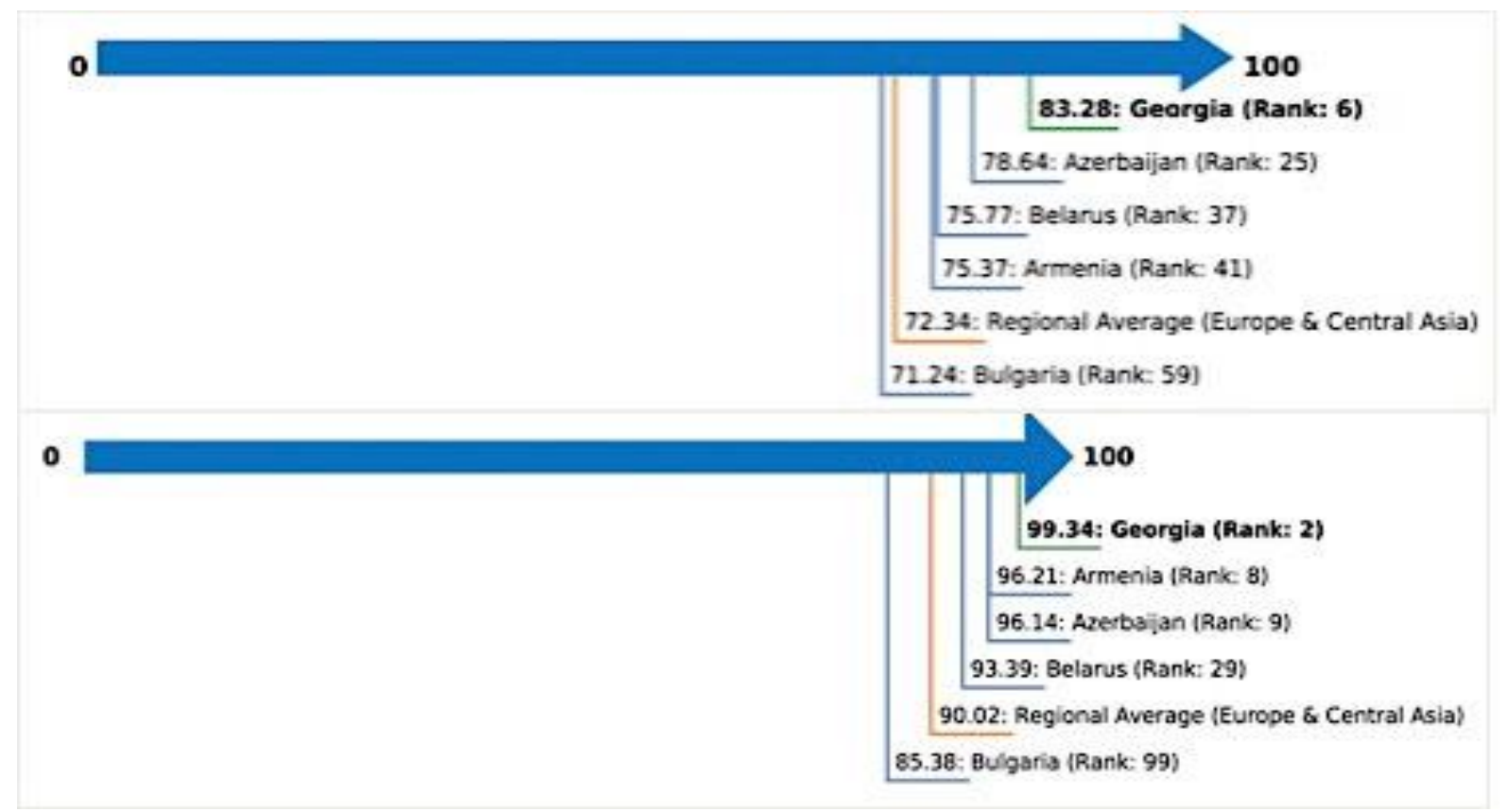

Figure 11. Easy of Doing Business Ranking, 2019 and Easy of Starting Business Score, 2019

Sources: World Bank, http://www.doingbusiness.org/en/data/exploreeconomies/georgia; http://www.doingbusiness.org/en/data/exploreeconomies/georgia 


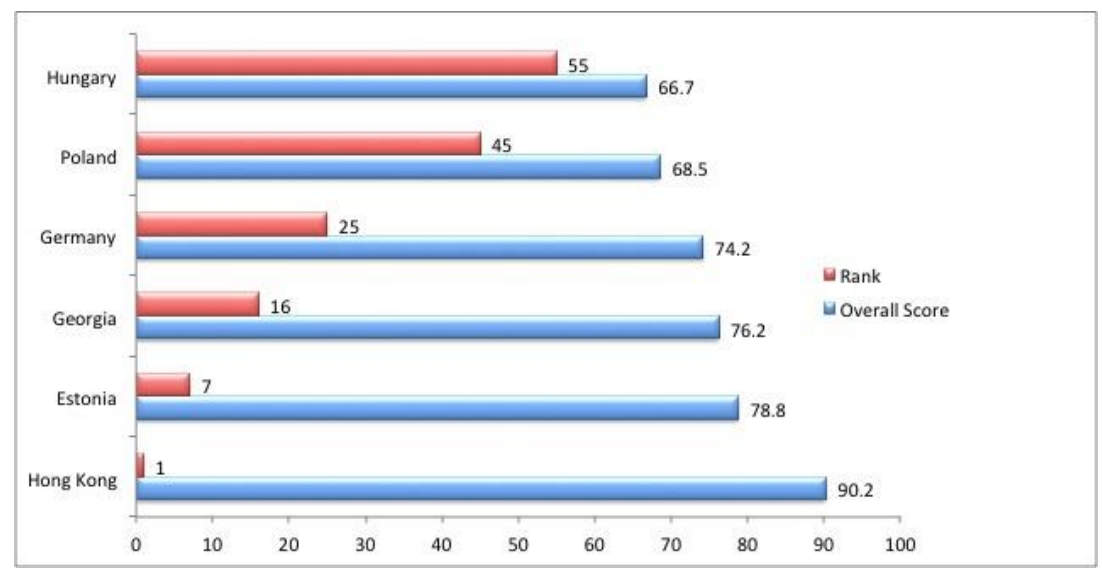

Figure 12. Country Ranking of the 2018 Index of Economic Freedom (Rank out of 180 countries)

Source: The Heritage Foundation, https://www.heritage.org/index/ranking

The findings highlight a further benefit for Georgia. China sees the New Silk Road as one of the most important incentives for its economic development, as it covers 65 countries and approximately $70 \%$ of the world population. Since speed counts in competition, new trade routs need to be developed between Asia, Africa, and Europe. Therefore, railways, ports, and roads are being built along the ancient Silk Road. Expectedly, freights will be increasingly transported by rail as it has clear advantage in comparison with the maritime routes. And Georgia will definitely play an important role, as the country is located less than 10 days overland from China, and within 4 days of any point in Europe. Georgia's first Deep Sea Port on the Black Sea will further enhance this connectivity, and give the opportunity for development of value added services, as it will reach the capacity of handling 100 million tons of cargo annually, and the world's largest container ships (Ministry of Economy and Sustainable Development of Georgia). This Anaklia Port Project, estimated at \$2.5 billion, is a joint venture between US- and Georgian firms and will be operated by an American company (Cowgill, 2017).

Furthermore, Baku-Tbilisi-Kars railway connection line located in the Tran-Caspian corridor connects Asia and Europe through Caspian to eastern Turkey. Under those circumstances, the link will give impetus to the development of the historic Silk Road, same as the TRACECA transport corridor, which will strengthen Georgia's position as a competitive route linking Europe and Asia (Ministry of Economy and Sustainable Development of Georgia). Nevertheless, some physical and software infrastructure problems along the Tran-Caspian corridor need to be addressed and solved. The global trade system will depend on standardization of border crossing procedures. Kazakhstan, Azerbaijan and Georgia, through the Trans-Caspian International Transport Route (TITR) initiative are working towards attracting Chinese east-west trade and investment to ensure that high costs on the Caspian crossing are reduced. TITR's activities are focused on competitive tariffs, customs and border management using digital technologies, and hence improving software infrastructure along the corridor. Individual countries are also simplifying border procedures by means of the 


\section{Macrothink}

Single Window system (Inan \& Yayloyan, 2018).

Regarding the EU-Georgian relations, the EU is the main trade partner of Georgia. EU trade with Georgia accounted for $0.1 \%$ of its total trade with a turnover of $€ 2.5$ billion in 2016 . EU exports to Georgia amounted to $€ 1.96$ billion in 2016 (Figure 13). The key export products are mineral products, machinery and appliances, chemical products and transport equipment, whereas the EU imports from Georgia include mineral products, agricultural products, base metals and chemical products. The EU imported goods to the value of $€ 551$ million from Georgia in 2016 (European Commission).
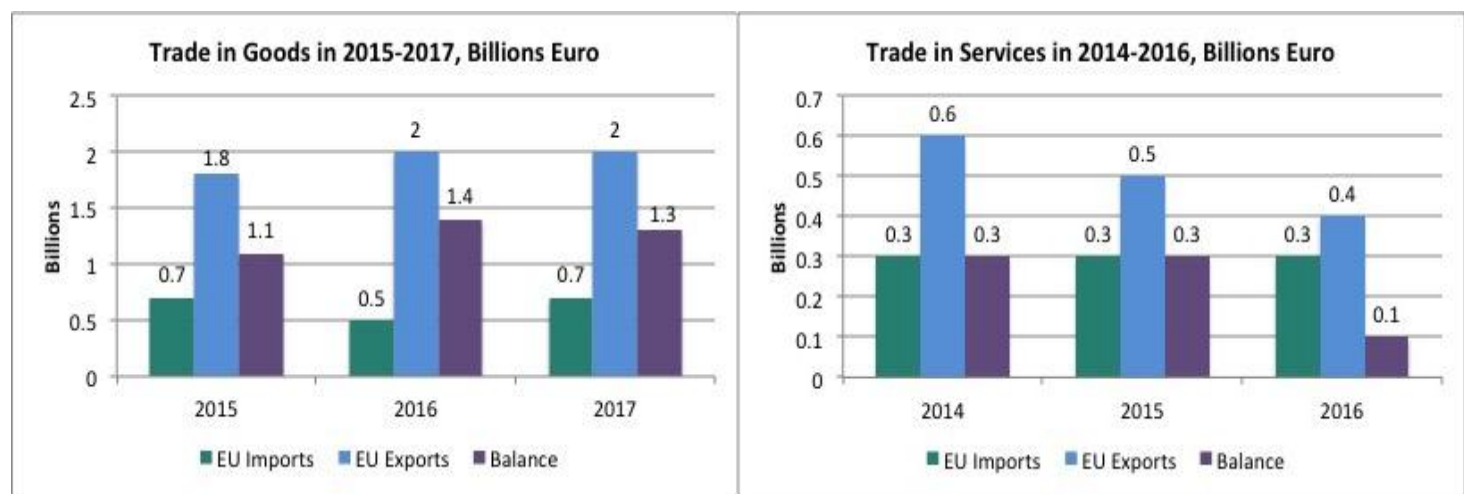

Figure 13. EU-Georgia Trade, 2015-2017

Source: European Commission Webpage

Tourism is another sector in Georgia, which could benefit from improved connectivity through the OBOR. At present, the country's quite dynamic and attractive tourism sector is developing fast. The amount of foreign visitors is growing every year. In 2018, the number of international traveler trips reached more than 8.6 million, which is $9.8 \%$ increase in comparison with the previous year (Figure 14). Moreover, international visitors for tourism purpose has been also augmented since 2016, while non-tourism visits to Georgia have changed only slightly between 2017 and 2018.

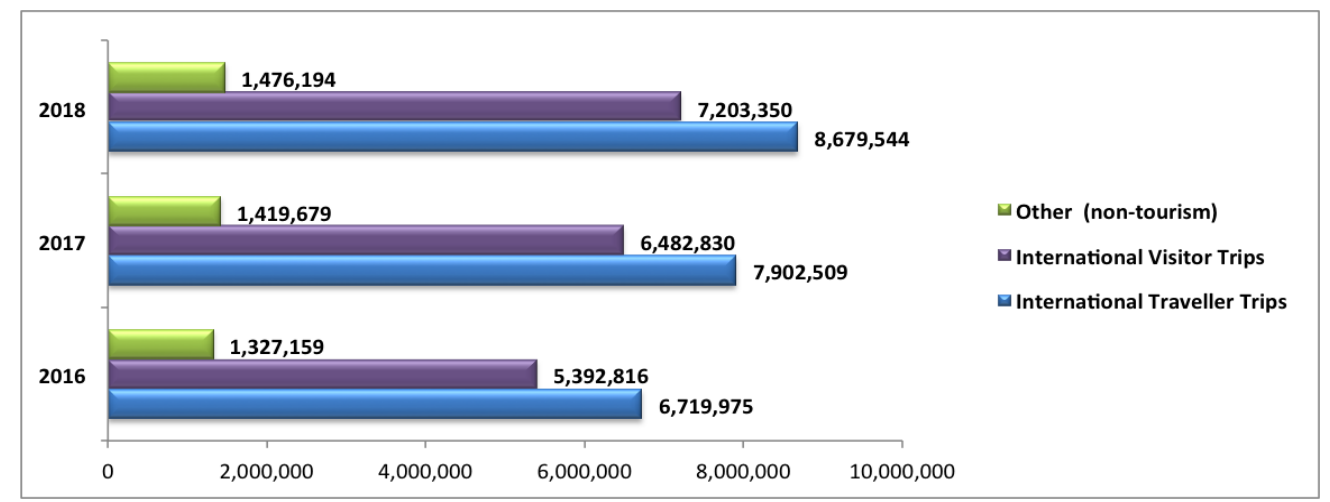

Figure 14. International Travel Classification in Georgia, 2016-2018

Source: Georgian National Tourism Administration, https://gnta.ge/statistics 
The most visitors arrived in Georgia from Europe; the number of European tourists visiting Georgia increased by about 12\% in 2018 in comparison with 2017 (Figure 15).

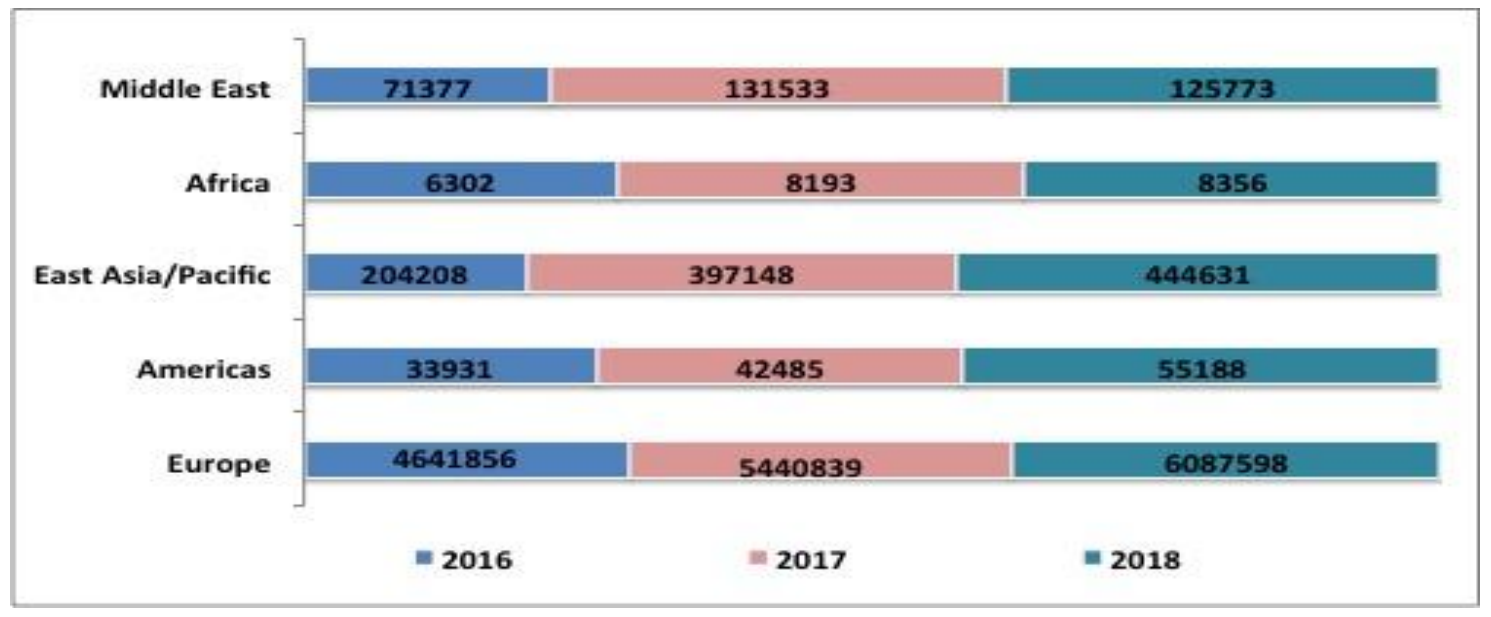

Figure 15. International Visitor Trips in Georgia by Regions, 2017-2018

Source: Data gathered from the Webpage of the Georgian National Tourism Administration

Additionally, Georgia is becoming more attractive for Chinese tourists as well. The number of Chinese tourists has augmented almost five times from 2010 to 2016. Visitors entered from China to Georgia increased by $75 \%$ in 2018. Totally 18179 Chinese tourists visited Georgia in 2017, while reaching 31855 visitors in 2018 (Georgian National Tourism Administration).

Significantly, Georgia with the EU Association Agreement, being active member of TITR founded by Georgia, Azerbaijan and Kazakhstan, is looking to China as a key trade partner and an investor. In general, the following four Projects are anticipated under the BRI investments concerning Georgia:

1) Construction of a new deep water seaport in Anaklia, on the Black Sea, to handle 100 million tons of cargo per year, with the capacity to receive large Panamax-type vessels;

2) Upgrading Georgia's railway network, and constructing two large tunnels to connect Georgia's east and west regions, leading to the increase of rail speed in the country by 50 percent and triple its capacity;

3) Construction of a Baku-Tbilisi-Kars railroad connecting Georgia and Azerbaijan to Kars, Turkey, and through it the European Union. The new railroad will allow 45 percent faster transport of 5 million tons of cargo and 1 million passengers annually from Asia to Europe. Its capacity can triple in subsequent years;

4) Expansion of the East-West Highway, Georgia's main transport road, with support from the World Bank, Asian Development Bank, and other donors (Djankov, 2016).

While the Baku-Tbilisi-Kars railway opened in 2017, the other initiatives are still in the process of implementation. Additionally, Anaklia planned for transshipment of oil and gas, aims to become a maritime hub for the region competing with the Turkish ports, and is 
envisaged as a future smart city harboring a special economic zone as well as industrial clusters. Thus, the increase of trade between the EU and China will enable Georgia to become a logistic hub.

To conclude, the OBOR in Georgia can facilitate development in poor regions, unlock investment potential and attract investment, create industrial bases across the country, provide faster transportation of goods from and to EU as well as from and to China, and therefore, get benefits from the Route.

\section{Conclusion}

The new global OBOR Initiative of China encompasses the revival of the ancient Silk Road promoting close cooperation between the Eurasian countries. Although it is too early to analyze the full potential of the OBOR because of its beginning stage, its positive implications are already obvious to the countries along the Route. First, developed infrastructure of trading partners facilitates exports due to reduced transportation costs. Another benefit of trade infrastructure is derived from improvements to the external trade balance, which lowers income inequity leading to reduction of poverty, and ultimately enhancing economic growth.

Countries are working together but also compete with each other for access to trade corridors. Although China provided an essential impetus, other actors have also their own interests. The Trans-Caspian route (Middle Corridor), which involves crossing several countries between China and Europe, among them Georgia as well, requires a comprehensive network of both hard and soft infrastructures, including harmonized customs and cross-border procedures. For this reason, the single-window system simplifies procedures and saves time. But also old infrastructure needs to be modernized to ensure that the full potential of this connectivity is achieved in the South Caucasus.

In summary, not only China, but also the EU has strong bilateral economic connections with all countries in the South Caucasus and with Turkey. Besides, Russia should be taken into account with its considerable influence in the South Caucasus. All things considered, the countries in the South Caucasus perceive Chinese investments as a means to balance Russia's influence in the region. Therefore, these countries should develop effective strategies to attract investments and flourish trade. Then, new technologies should be used to upgrade industrial capacities by focusing on their competitive advantages. Further, the countries should cooperate and coordinate their activities to remove barriers across borders along the corridors. In essence, these countries can benefit from investment and financing infrastructure development. It should be emphasized, that both soft and hard infrastructures are crucial for the successful implementation of the BRI.

Moreover, Georgia can become an economic hub in the region taking into consideration not only its strategic location but also excellent conditions for foreign investors. Asian products and energy resources reach Europe faster through Georgia, and Free Trade Regimes make it possible to access more than 2.3 billion customer market. As a result, trade turnover can considerably expanded. Georgia can improve corridor performance through legislative 
measures, technical standards, regulatory reforms, as well as develop physical infrastructure and logistics networks. Consequently, quality and competitiveness of transport and logistic services can be improved.

Finally, further studies are required to reveal empirically the complete potential impacts of BRI on the concerning countries in terms of trade, transportation, and labor markets; in particular a future research should examine whether competitive labor costs offer advantages in attracting investments in the South Caucasus. Additionally, more comprehensive gravity model should be built to ascertain exact trade potential between BRI countries reflecting economic benefits from the Road.

\section{References}

Beckwith, Ch. I. (2009). Empire of the Silk Road: A History of Central Eurasia from the Bronze Age to the Present. Princeton and Oxford: Princeton University Press.

Bond, I. (2016). Russia and China: Partners of Choice and Necessity? The Centre for European Reform. [Online] Available: https://www.cer.eu/publications/archive/report/2016/ russia-and-china-partners-choice-and-necessity

Charaia, V., \& Papava, V. (2017). Belt and Road Initiative: Implications for Georgia and China-Georgia Economic Relations. China International Studies, 127-139.

Coulibaly, S., Deichmann, U., Dillinger, W. R., Ionescu-Heroiu, M., Kessides, I. N., Kunaka, Ch., \& Saslavsky, D. (2012). European Cities: New Realities along the Silk Road. Europe and Central Asia Reports. Washington D.C: The World Bank.

https://doi.org/10.1596/978-0-8213-9581-3

Cowgill, M. (2017, October 28). The New Silk Road: The US Needs a Free Trade Deal with Georgia. The Hill, [Online] Available:

https://thehill.com/opinion/finance/357609-the-new-silk-road-the-us-needs-a-free-trade-dealwith-georgia

De, P., \& Iyengar, K. (2014). Developing Economic Corridors in South Asia. Asian Development Bank.

Denoon, D. B. H. (2015). China, The United States, and the Future of Central Asia: U.S.-China Relations. Vol. 1. New York and London: New York University Press. https://doi.org/10.18574/nyu/9781479844333.001.0001

Djankov, S. (2016). The Belt and Road Initiative in the Former Socialist Bloc. In: Djankov, S. \& Miner, S. (Eds.), China's Belt and Road Initiative: Motives, Scope, and Challenges, Chapter 6. Peterson Institute for International Economics.

Enterprise Incubator Foundation. (2017). State of the Industry Report: Information and Telecommunication Technologies Sector in Armenia.

European Commission. (2019). [Online] Available:

http://ec.europa.eu/trade/policy/countries-and-regions/countries/georgia 
Eurostat. (2019). [Online] Available: https://ec.europa.eu/eurostat/data/database

Georgian National Investment Agency. (2019). [Online] Available:

https://investingeorgia.org/en

Georgian National Tourism Administration. (2019). [Online] Available:

https://gnta.ge/statistics

Herrero, A. G., \& Xu, J. (2016). China's Belt and Road initiative: Can Europe expect trade gains?. Bruegel: Working Paper No. 5. [Online] Available:

http://bruegel.org/wp-content/uploads/2016/09/WP-05-2016.pdf

Hualing Group. (2018). Retrieved from http://hualing.ge/language/en/hualing-georgia

Inan, F., \& Yayloyan, D. (2018). New Economic Corridors in the South Caucasus and the Chinese One Belt One Road. The Economic Policy Research Foundation of Turkey (TEPAV). [Online] Available: http://hdl.handle.net/11540/8283

Iron Silk Road. (2019). [Online] Available: http://www.mkrailway.ge/index.php?lan=eng

Israfilbayova, S. (2017, June 15). TITR International Association to Cooperate with China. Azernews, [Online] Available: https://www.azernews.az/business/114765.html

Larsen, J. (2017). Georgia: The Black Sea Hub for China's 'Belt and Road'. The Diplomat. [Online] Available:

https://thediplomat.com/2017/05/georgia-the-black-sea-hub-for-chinas-belt-and-road

Li, Y., \& Schmerer, H.-J. (2017). Trade and the New Silk Road: Opportunities, Challenges, and Solutions. Journal of Chinese Economic and Business Studies, 15(3).

https://doi.org/10 .1080/14765284.2017.1347473

Ministry of Customs and Trade of the Republic of Turkey (2018). [Online] Available: https://www.trade.gov.tr

Ministry of Economy and Sustainable Development of Georgia. (2019). [Online] Available: www.economy.ge

Ministry of Transport and Infrastructure of the Republic of Turkey. (2018). [Online] Available: www.udhb.gov.tr/eng

Mount, I. (2014). Spain to China by Rail: A 21st Century Silk Road Riddled with Obstacles. Fortune. [Online] Available: http://fortune.com/2014/12/24/spain-china-\%20rail-trade

National Statistics Office of Georgia (GEOSTAT). (2019). [Online] Available:

www.geostat.ge/index.php?lang=eng

Pantucci, R., \& Lain, S. (2016). Tbilisi Silk Road Forum: Next Steps for Georgia and the Silk Road. Workshop Report. Retrieved from Royal United Services Institute for Defence and Security Studies (RUSI).

https://rusi.org/sites/default/files/201608_wr_tbilisi_silk_road_forum.pdf 


\section{Macrothink}

Business and Economic Research

ISSN 2162-4860

2019, Vol. 9, No. 1

Railway Technology. (2019). [Online] Available:

https://www.railway-technology.com/projects/ baku-tbilisi-kars

Ramasamy, B., Yeung, M., Utoktham, Ch., \& Duval, Y. (2017). Trade and Trade Facilitation along the Belt and Road Initiative Corridors. Asia-Pacific Research and Training Network on Trade (ARTNeT). Working Paper, No.172.

Shepard, W. (2017). How Azerbaijan, Georgia, And Turkey Subverted Russia And Isolated Armenia With New Railway. Forbes,

https://www.forbes.com/sites/wadeshepard/2017/10/30/new-silk-road-azerbaijan-georgia-and -turkey-unite-over-new-rail-line-armenia-further-isolated/\#237b67bd3aff

Statista - The Portal for Statistics. (2019). [Online] Available:

https://www.statista.com/statistics/ 440757/ export-of-goods-to-armenia

The Heritage Foundation (2018). Index of Economic Freedom, 2018. [Online] Available:

https://www.heritage.org/index/ranking

The Observatory of Economic Complexity (OEC). (2019). [Online] Available:

https://atlas.media .mit.edu

The World Bank (2019). [Online] Available:

http://www.doingbusiness.org/en/data/exploreeconomies/georgia

The World Bank Data (2019). [Online] Available: https://data.worldbank.org

Trans-Caspian International Transport Route (TITR) (2019). [Online] Available:

http://titr.kz/en

Tskhovrebova, A. (2016). Chinese Investment's Silk Road. Forbes (in the Georgian language), [Online] Available: http://forbes.ge/news/1581/Cinuri-investiciebis-abreSumis-gza

Turp, C. (2017, October 30). Azerbaijan, Georgia, Turkey launch new "Silk Rail” Link. Emerging Europe: The Gateway to the Region, [Online] Available:

https://emergingeurope.com/news /azerbaijan-georgia-turkey-launch-new-silk-rail-link

United Nations Educational, Scientific and Cultural Organization (UNESCO). (2019). About the Silk Road. [Online] Available: https://en.unesco.org/silkroad/about-silk-road

Van Dijk, M. P., \& Martens, P. (2016). The Silk Road and Chinese interests in Central Asia and the Caucasus: the Case of Georgia. Maastricht School of Management, Working Paper No. 2016/12. [Online] Available:

http://web2.msm.nl/RePEc/msm/wpaper/MSM-WP2016-12.pdf

World Integrated Trade Solution (WITS). (2019). [Online] Available:

https://wits.worldbank.org

World's Top Exports (WTEx). (2019). [Online] Available:

http://www.worldstopexports.com/azerbaijans-top-10-exports 


\section{Copyright Disclaimer}

Copyright for this article is retained by the author(s), with first publication rights granted to the journal.

This is an open-access article distributed under the terms and conditions of the Creative Commons Attribution license (http://creativecommons.org/licenses/by/3.0/). 